\title{
A palynology and paleoenvironmental study of a section from the Amansiodo-1 well, Anambra Basin, southeastern Nigeria
}

\author{
Jacinta Nkiru Chukwuma-Orji, Edward Agboneni Okosun, \\ Joseph Clement Ekom, James Femi Abolarin \\ Federal University of Technology, Department of Geology; Minna, Nigeria; e-mail: jacinta@futminna.edu.ng

\begin{abstract}
(C) 2017 Authors. This is an open access publication, which can be used, distributed and reproduced in any medium according
\end{abstract} \\ to the Creative Commons CC-BY 4.0 License requiring that the original work has been properly cited.
}

Received: 07 March 2017; accepted: 30 October 2017

\begin{abstract}
Palynological analysis was carried out on twenty (20) ditch cutting samples from a section (1284.73$1496.57 \mathrm{~m}$ ) of the Amansiodo-1 well, Anambra Basin, southeastern Nigeria with the aim of determining the age, biozone, and depositional environment of the sediments within the depth interval. The laboratory techniques of digesting sediments in hydrochloric and hydrofluoric acids for silicates and carbonates removal were followed to process the samples for the recovery of palynomorphs. Fifty two (52) palynomorph specimens were recovered. An assemblage zone of Echitriporites trianguliformis Zone has been established. The section was dated to the upper Maastrichtian due to the occurrences of age diagnostic marker species such as: Cingulatisporites ornatus, Distaverrusporites simplex, Proteacidites sigalii, Dinogymnium cf auclaense, Echitriporites trianguliformis and Retidiporites magdalensis. Based on the palynomorph marine index and environmental indicator flora, the section was inferred to be deposited in marine to brackish (coastal) environments with little influence of fresh water.
\end{abstract}

Keywords: southeastern Nigeria, Anambra Basin, palynology, paleoenvironment, Amansiodo-1 well

\section{INTRODUCTION}

The Amansiodo-1 well is located at the latitude $6^{\circ} 87^{\prime} 15^{\prime \prime} \mathrm{N}$ and longitude $7^{\circ} 68^{\prime} 25^{\prime \prime} \mathrm{E}$ in the Anambra Basin, in eastern Nigeria (Fig. 1). Palynological information about the age and paleoenvironment of deposition of sedimentary rocks within the Anambra Basin has been published. Ola-Buraimo \& Akaegbobi (2013) carried out sedimentological, palynological age dating and the paleoenvironment reconstruction of the Nzam-1 well in Anambra Basin. Chiaghanam et al. (2013) carried out lithofacies, palynology and paleoenvironmental studies of early Campanian to mid-Maastrichtian deposits of Udi and environs in the Anambra Basin, south eastern Nigeria.
The researchers used diagnostic palynomorph species and the coarsening upward sequence of the lithofacies in the Mamu Formation to suggest a decrease in sea level, and the intercalation of siltstone/sandstone and shale in the lithofacies of Enugu Shale, with a high abundance and diversity of palynomorphs taken to infer a shallow-marine environment with tidal influence. The diagnostic palynomorph species recovered include; Laevigatosporites ovatus, Leiotriletes adriennis, Echitriporites trianguliformis, Longapertites marginatus, Cyathidites minor, Operculodinium centrocarpum, Areoligera senoniensis, Spiniferites ramosus, Ceratiopsis sp., Paleocystodinium sp., Dinogymnium accuminatum, Spiniferites ramosus and Cordosphaeridium inorders. 


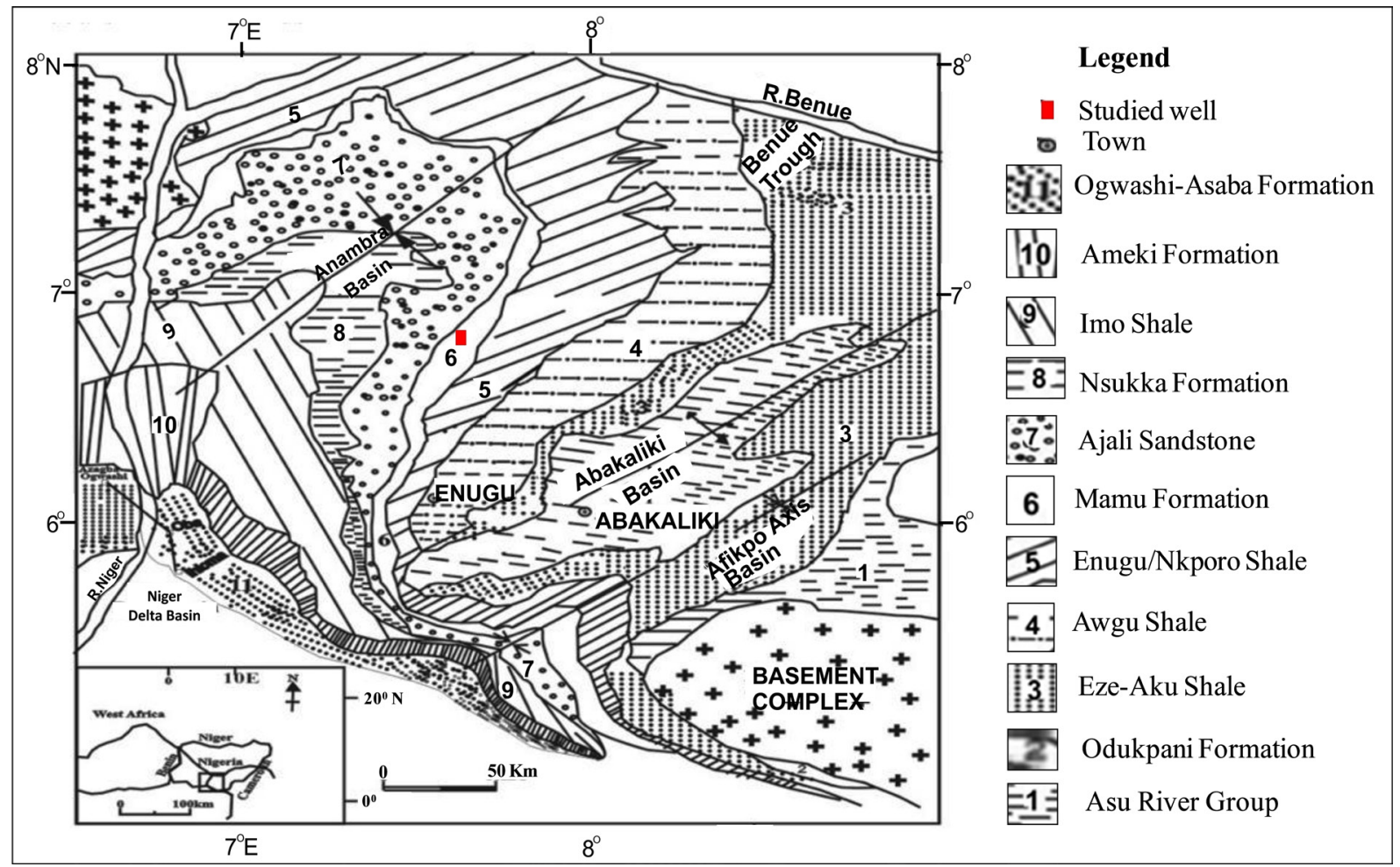

Fig. 1. Geological map of south-eastern Nigeria and the location of the Amansiodo-1 well (modified after Chiaghanam et al. 2013)

Van Hoeken-Klinkenberg (1964) carried out palynological analysis of the sediment from the upper Enugu Shale, Mamu and Nsukka formations using materials collected from G.S.N. Boreholes number 1001, 1108 and 1122. The author ascribed a Maastrichtian age to the formations based on the presence of marker species such as Cingulatisporites ornatus, Germmatricolpites scrabatus, Longapertites marginatus and Syncolporites marginatus. Salami (1990) worked on the palynology of the lower coal measures (Mamu Formation) and dated the sediments to the Campanian-Maastrichtian and as well inferring the depositional environment as a freshwater swamp to a marsh environment using the recovered palynomorphs. Umeji \& Edet (2008) noted that the paleoenvironments of the deposition of Nsukka Formation in the Anambra Basin oscillated from the lower to upper deltaic plains, varying from tidal flat, lagoon, tidal bar, raised bogs and reed swamp in the north to near shore open marine condition in the south. Ogala et al. (2009) used palynological data to study the middle-upper Maastrichtian Mamu coal facies.
Ogala (2010) carried out palynological and biostratigraphic studies of coal measures in the Anambra Basin, southeastern Nigeria. The researcher established a Longapertites marginatus acme zone in the lower section, dated to the middle Maastrichtian, and a Spinizonocolpites baculatus assemblage zone in the upper part, dated to the upper Maastrichtian. Okoro (2012) described the palynology of the Afikpo sub-basin of the Anambra Basin. The researcher recovered palynomorphs such as Longapertites marginatus, Monocolpites marginatus, Proxapertites cursus, Mauritidites crassi bacculatus and Andallussiella polmorpha, Senegalinium bivacatum and Coronifera tubulosa, which were used to date the studied section to the Campanian-Maastrichtian. Soronnadi-Ononiwu et al. (2012) carried out palynological and paleoenvironmental studies on the Mamu Formation in the Anambra Basin. The authors dated the Mamu Formation to the Maastrichtian using palynomorphs recovered such as Echitriporites trianguliformis, Ephedripites magdalensis and Cingulatisporites ornatus. Seventy percent $(70 \%)$ of the recovered palynomorphs were terrestrial in origin, suggesting a continental 
depositional environment with minor marine incursion. However, palynological work on the Amansiodo-1 well has not been reported or published. This work, therefore, aims to identify the recovered palynomorphs and use them to zone, date and infer the depositional environment of the section of the Amansiodo-1 well. An understanding of the age and paleoenvironment of the deposition of sediments is important in basin evaluation and the successful exploration of both organic and inorganic mineral resources.

\section{THE GEOLOGICAL SETTING AND STRATIGRAPHY OF THE ANAMBRA BASIN}

The Anambra Basin is associated with the tectonic event episode that occurred in the Benue Trough in the Santonian age and resulted in the deformation, folding, faulting and uplift of the pre-Santonian sediments. The Anambra Basin evolved as a depression to the west of the uplift (Benkhelil
\& Guiraud 1980). The Anambra Basin is a depocenter in which sediments from the Campanian to the Maastrichtian were laid.

The stratigraphic setting of the southern part of Nigeria comprises three major cycles. The first two have been dated to the pre-Santonian while the third cycle belongs to the post-Santonian which is found in the Anambra Basin (Nwajide 1990, 2005). The strongly folded Albian-Coniacian succession (pre-Santonian) sediments are overlain by the nearly flat-lying Campanian-Maastrichtian succession. The oldest sediment in the Anambra Basin is the Nkporo Group (Nwajide 1990). This was deposited in the basin in the late Campanian, comprising Nkporo Shale, Enugu Shale, Owelli Sandstone, Afikpo Sandstone, Otobi Sandstone and Lafia Sandstone (Tab. 1) (Reyment 1965, Onyekuru et al. 2017). The Mamu Formation overlies the Nkporo Group and was deposited in the early Maastrichtian (Fig. 1). It comprises a succession of siltstone, shale, coal seam and sandstone (Kogbe 1989).

Table 1

Stratigraphic correlation of the southeastern Nigerian basins (Nwajide 2005, Onyekuru et al. 2017)

\begin{tabular}{|c|c|c|c|c|c|c|c|c|}
\hline Age & Basin & \multicolumn{7}{|c|}{ Stratigraphic Units } \\
\hline $\begin{array}{l}\text { Oligocene- } \\
\text {-Recent }\end{array}$ & \multirow{3}{*}{$\begin{array}{l}\text { Niger } \\
\text { Delta }\end{array}$} & \multicolumn{4}{|c|}{ Ogwashi-Asaba Fm } & \multicolumn{3}{|c|}{ Benin Formation } \\
\hline Eocene & & \multicolumn{4}{|c|}{$\begin{array}{c}\text { Arneki/Nanka Fm/Nsugbe Sandstone (Ameki } \\
\text { Group) }\end{array}$} & \multicolumn{3}{|c|}{ Agbada Formation } \\
\hline Thanetian & & \multicolumn{4}{|c|}{ Imo Formation } & \multicolumn{3}{|c|}{ Akata Formation } \\
\hline Danian & \multirow{4}{*}{$\begin{array}{l}\text { Anambra } \\
\text { Basin }\end{array}$} & & \multicolumn{6}{|c|}{ Nsukka Formation } \\
\hline \multirow{2}{*}{ Maastrichtian } & & & \multicolumn{6}{|c|}{ Ajali Formation } \\
\hline & & & \multicolumn{6}{|c|}{ Mamu Formation } \\
\hline Campanian & & $\begin{array}{l}\text { Nkporo } \\
\text { Fm }\end{array}$ & $\begin{array}{l}\text { Nkporo } \\
\text { Shale }\end{array}$ & $\begin{array}{l}\text { Enugu } \\
\text { Fm }\end{array}$ & Owelli Ss & Afikpo Ss & Otobi Ss & Lafia Ss \\
\hline Santonian & $\begin{array}{c}\text { Southern Benue } \\
\text { Trough }\end{array}$ & \multicolumn{7}{|c|}{ Agwu Formation } \\
\hline
\end{tabular}


The Ajali Formation (Maastrichtian) overlies the Mamu Formation (Reyment 1965, Nwajide 1990). The Ajali Formation is dominantly unconsolidated, coarse - fine grained, poorly indurated with mudstone and siltstone facies (Kogbe 1989). The Ajali Sandstone is overlain by the diachronous Nsukka Formation (Maastrichtian-Danian) which is also known as the Upper Coal Measure (Reyment 1965). On top of the Nsukka Formation is the Imo Shale which is dated to the Paleocene age (Nwajide 1990). It comprises clayey shale with occasional ironstone and thin beds of ironstone in which carbonized plant remains may occur (Kogbe 1989). The Eocene stage was characterized by a regressive phase that led to the deposition of the Ameki Formation.

\section{METHODS}

A total number of twenty (20) ditch cutting samples from the Amansiodo-1 well collected from Nigerian Geological Survey Agency (NGSA) Kaduna, were subjected to palynological analysis. The sample preparation and analysis were made in the Crystal Age Laboratory Nigeria Limited, Ikorodu, Lagos State, Nigeria.

The lithologic description of the ditch cutting samples for preparation of lithologic log was based on the physical inspection of the samples with the aid of magnifying hand lens and a chart for the textural analysis of clastic sediments. Texturally, clastic sediments made of particles smaller than $0.004 \mathrm{~mm}$ with varying degrees of fissility, breaking into thin layers (those split easily with a penknife into mm-thick flakes); often splintery and usually parallel to the indistinguishable bedding plane because of the parallel orientation of clay mineral flakes are known as shale (Hallsworth \& Knox 1999).

The laboratory techniques of digesting sediments in hydrochloric and hydrofluoric acids for silicates and carbonates removal were followed to process the samples for the recovery of palynomorphs. Twenty five grams of each sample was weighed, poured into well labeled plastic cups and arranged in a fume cupboard. Each sample was digested for 35 minutes in $40 \%$ hydrochloric acid for removal of carbonate and 24 hours in
$40 \%$ hydrofluoric acid for the removal of silicate. Sieving was done using a brason sonifier to filter away any remaining inorganic matter (silicates, clay, and mud) and heavy minerals to concentrate organic matters present in the sample. Controlled oxidation was given to the sieved residue using concentrated nitric acid $\left(\mathrm{HNO}_{3}\right)$. The residue was stained with Safranin O, before being mounted on glass slides and analyzed with the aid of an Olympus Binocular light transmitted microscope.

The paleoenvironment of the deposition of the studied section was deduced using the palynomorph marine index (PMI). The palynomorph marine index is a semi quantitative interpretation technique, useful in the determination of depositional environment (Helenes et al. 1998). PMI is the ratio of the abundance of marine derived palynomorphs to terrestrially derived palynomorphs, expressed in percentages. It is calculated using the formula (Helenes et al. 1998):

$\mathrm{PMI}=\left(R_{m} / R_{t}+1\right) \times 100$,

where $R_{m}$ is richness or number of marine derived palynomorph (Dinoflagellates + Acritarch + Foraminifera lining + Prasinophytes) taxa per sample and $R_{t}$ is richness or number of terrestrially derived palynomorphs (Pollen + Spores + Fungal remains) taxa per sample.

High, low and nil values of palynomorph marine index indicate a marine, brackish and fresh water environment respectively.

\section{RESULTS}

The results of the lithologic description and the palynological analysis are presented in Figure 2. The lithology of the studied section is composed of shale. This is because the samples were observed to be fissile and fine grained with a particle size of $0.004 \mathrm{~mm}$. They were also hard, black in color and split into thin flakes along the bedding fissility. Fifty two (52) palynomorph specimens were recorded. The recovered palynomorphs are abundant, diverse, and well preserved at almost all depth intervals (Figs. 2, 3). The palynofloral assemblages were dominated by pollen, spores and dinoflagellate cysts. 


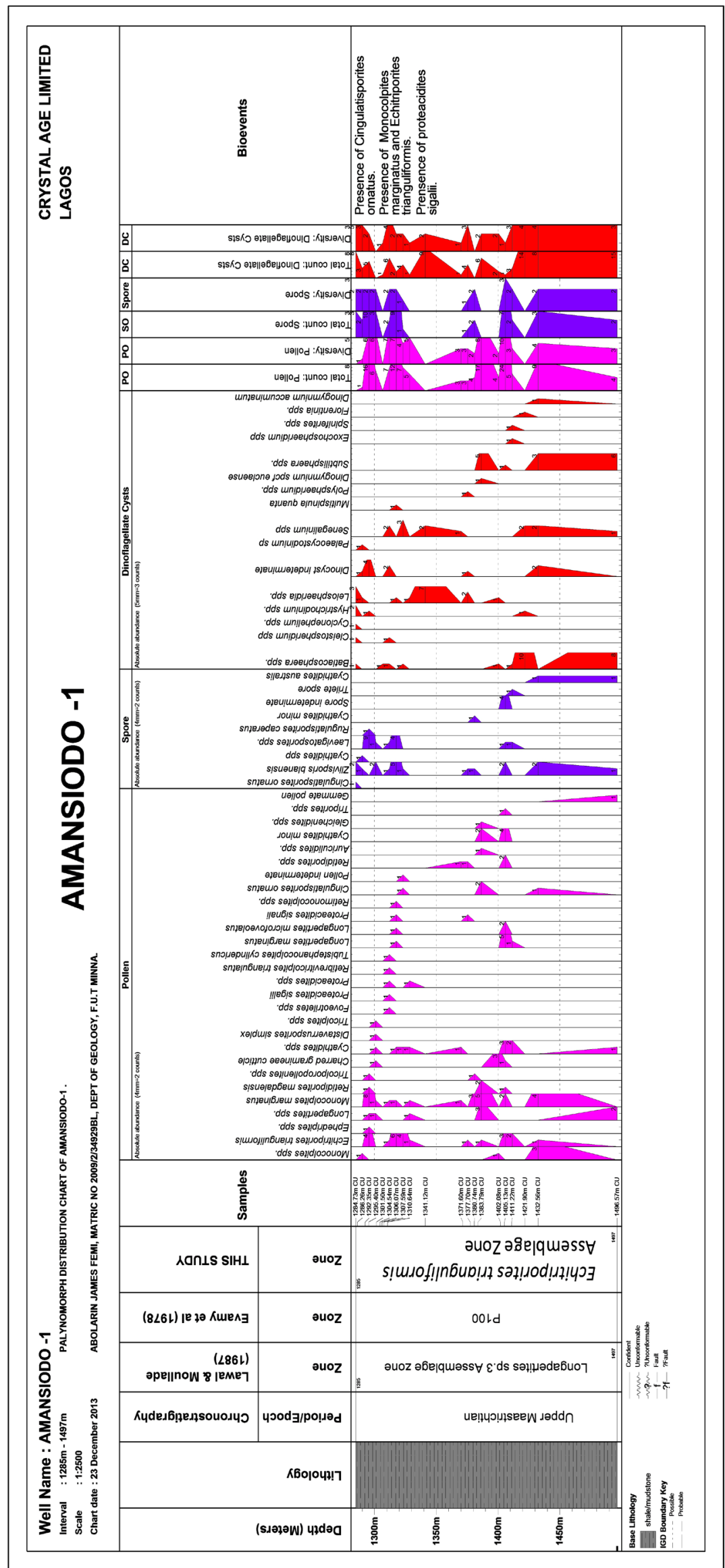

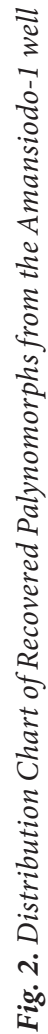




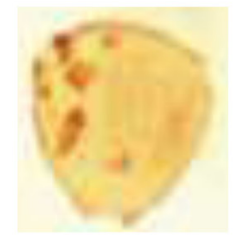

A

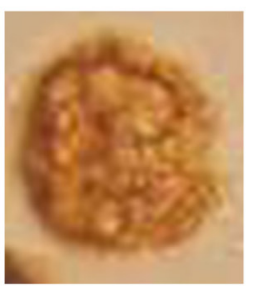

F

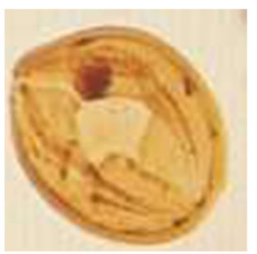

$\mathrm{K}$

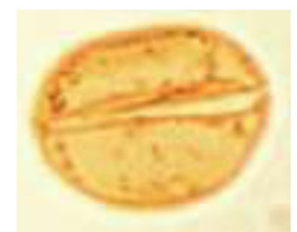

B

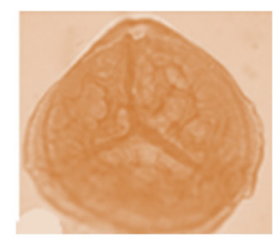

G

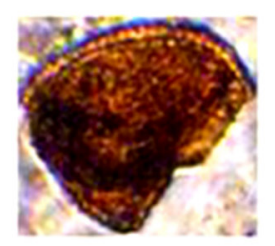

$\mathrm{L}$

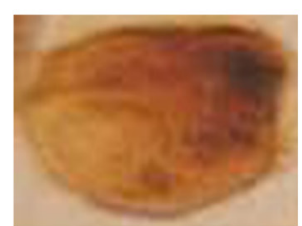

C

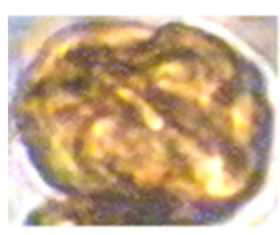

$\mathrm{H}$

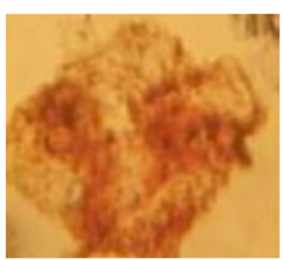

M

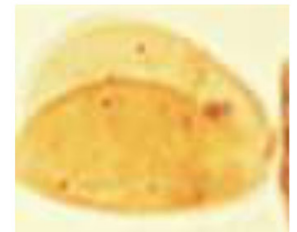

$\mathrm{D}$

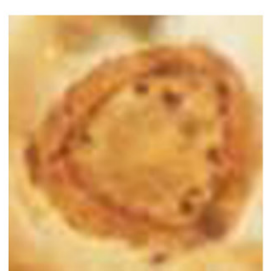

I

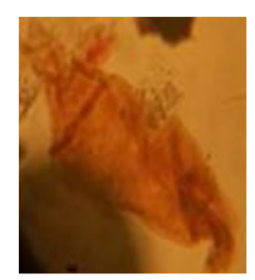

$\mathrm{N}$

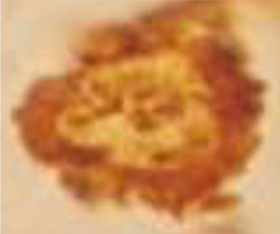

E
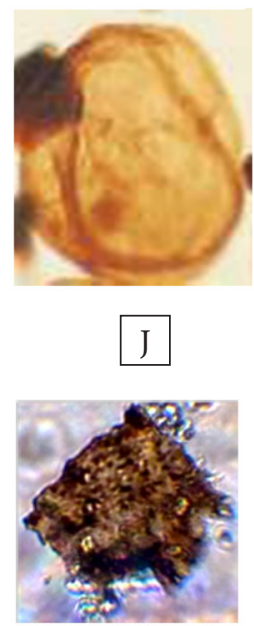

O

Fig. 3. Recovered palynomorphs photomontage (×400): A) Echitriporites trianguliformis Van Hoeken-Klinkerberg 1964; B) Longapertites marginatus Van Hoeken-Klinkerberg 1964; C) Retidiporites magdalenensis Van der Hammen and Garcia 1966; D) Longapertites marginatus Van Hoeken-Klinkerberg 1964; E) Distaverrusporites simplex Muller 1968; F) Zlivisporis blanensis Ogala et al. 2009; G) Zlivisporis blanensis Pacltova 1961; H) Monocolpites marginatus Van Der Hammen 1954; I) Cingulatisporites ornatus Van Hoeken-Klinlenberg 1964; J) Tricolpites sp.; K) Tricolporopollenites sp.; L) Foveotriletes sp.; M) Dinogymnium accuminatum Clarke and Verdier 1967; N) Palaeocystodinium sp. Alberti, 1961; O) Senegalinium sp.

The pollen taxa recovered are: Echitriporites trianguliformis, Longaperitites marginatus, Longapertites sp, Longapertites microfeveolatus, Monocolpites marginatus, Ephedripites sp, Retidiporites magdalenesis, Proteacidites sigalii, Auriculiidites sp., Rugulatisporities caperatus, Tubistephanocolporites cylindricus, Distaverrusporites simplex, Retribrevitricolpites triangulatus, Triporites sp. and Retimonocolpites sp. The spores recorded include: Cyathidites minor, Zlivisporis blanensis, Rugulatisporites caperatus, Cyathidites australis, Cingulatisporites ornatus, Cyathidites sp., Laevigatosporites sp., and Trilete spore.

The marine dinoflagellate cysts recorded include Senegalinium sp., Batiacasphaera sp., Dinogymnium cf auclaense, Hystrichodinium sp., Paleocystodinium sp., Leiosphaeridia sp.Polysphaeridium sp.,Exochosphaeridium sp., Spiniferites sp., Florentinia sp., Cleistospheridium sp.,
Dinogymnium accuminatum, Multispinura quanta and Subtilispaera sp.

\section{DISCUSSION}

The recovered palynomorph species were used for biostratigraphic zonation, age dating and the paleoenvironmental interpretation of the stratigraphic interval studied in the Amansiodo-1 well.

\section{Biostratigraphic zonation and age dating Echitriporites trianguliformis Zone (assemblage zone)}

Interval: $1284.73-1496.57 \mathrm{~m}$.

An assemblage zone is characterized by an assemblage of three or more fossil taxa. The palynomorphs taxa that characterize this zone include: Echitriporites trianguliformis, Longapertites sp., Monocolpites sp., Monocolpites marginatus, 
Retidiporites magdalenensis Zlivisporites blanensis, Senegalinium sp. and Baltiacosphaera sp. The upper boundary of this zone is placed at the depth of $1284.73 \mathrm{~m}$ (the first sample analyzed) with the uppermost documented occurrence or first downhole occurrence of Zlivisporites blanensis, Monocolpites sp., Hystrichodinium sp., Leiosphaeridia sp., while the lower boundary is placed at the depth of $1496.57 \mathrm{~m}$ (last sample analyzed) with the lowermost occurrence or last downhole occurrence of Longapertites sp., Cyathidites sp, Gemmate pollen, Zlivisporites blanensis, Cyathidites australis, Senegalinium sp., Subtiliphaera sp. The age of this zone is therefore inferred to be the upper Maastrichtian.

Echitriporites trianguliformis has a stratigraphic range of Campanian-Maastrichtian to Eocene in Sudan (Eisawi 2015) and the CampanianMaastrichtian in Nigeria (Edet 1992). Zlivisporis blanensis has a stratigraphic range of Coniacian-Paleocene. It has also been reported from the Maastrichtian in Somalia, Late Cretaceous in Nigeria and from the Turonian to Early Maastrichtian in Sudan (Eisawi 2015). Monocolpites marginatus has a stratigraphic range of Campanian-Paleocene. Previous records of Monocolpites marginatus in Africa range from the Campanian-Maastrichtian in Nigeria and Sudan and to the Paleocene to Eocene in Nigeria (Eisawi 2015). The marker species Proteacidites sigalii was originally described from the Senonian (Coniacian to Maastrichtian) in Gabon and later reported from the Coniacian to Maastrichtian of a number of West African basins (Campanian-Maastrichtian of Egypt, the Maastrichtian of Nigeria and Sudan) (Eisawi 2015). Retidiporites magdalenensis which is Coniacian to Maastrichtian in age has been recorded from the Maastrichtian of Nigeria, Egypt and Somalia (Eisawi 2015).

The studied section is further confirmed to be upper Maastrichtian because of the high occurrence of the species reported to be restricted to the Maastrichtian such as Echitricolporites trianguliformis, Cingulatisporites ornatus, Distaverrusporites simplex, Proteacidites sigali, Dinogymnium sp., Dinogymnium sp. cf auclaense and Retidiporites magdalenensis (Soronnadi-Ononiwu et al. 2012). The Dinogymnium lineage became extinct in the Maastrichtian (Stover et al. 1999). However, the abundant record of the diagnostic marker species, especially Echitricolporites trianguliformis,
Monocolpites marginatus, Proteacidites sigalii, Leiosphaeridia sp. and Senegalinium sp. suggest an upper Maastrichtian age. The established zone of this study falls within the Longaperites sp. 3 Zone (assemblage zone) of Lawal \& Moullade (1987) and the P100 zone of Evamy et al. (1978). This is because most of the recovered miospores in this study occurred within the established zones of the above authors.

\section{Paleoenvironment of deposition}

Inference regarding the paleodepositional environment of the studied well was made based on the biofacies information interpreted from the qualitative and quantitative evaluation of the palynomorph assemblages and the integration of the lithologic description of the section. The parameters considered in the interpretation of the paleoenvironment are: the palynological marine index, presence/absence of environmental diagnostic marker species.

From the PMI plot (Fig. 4), intervals 1284.73$286.35 \mathrm{~m}, 1301.50 \mathrm{~m}, 1310.64 \mathrm{~m}$ and $1411.22 \mathrm{~m}$ respectively have high palynomorph marine index values of $75 \%$ and above. They are suggestive of deposits within a marine environment. These intervals also consist of moderate records of pollen and spores with an abundant dinoflagellate cyst. The dinoflagellate cysts recovered include Subtilisphaera sp., Senegalinium sp., Leiosphaeridia sp., Baltiacosphaera sp., Florentinia sp., Dinogymnium c.f eunclaense, Dinogymnium sp. and Dinogymnium accuminatum. The presence of Spiniferites sp. and Hystrichodinium sp. indicate an open marine (inner neritic to outer neritic) environment (Stover et al. 1999). Cyclonephelium sp., Polysphaeridium sp. and Cleistophaeridium sp. are indicative of slightly saline condition and near shore environment (Stover et al. 1999, Okeke \& Umeji 2016). The above assemblages suggest that the sediments of these intervals were deposited within a marine environment.

Also the following intervals $1295.40 \mathrm{~m}, 1304.54-$ $1307.59 \mathrm{~m}, 1341.12-1371.60 \mathrm{~m}, 1380.74-1383.79 \mathrm{~m}$, $1405.13 \mathrm{~m}$, and $1421.90-1496.57 \mathrm{~m}$ respectively were deposited in brackish water due to a low palynomorph marine index of less than $75 \%$ while other intervals such as $1377.70 \mathrm{~m}$ and $1402.08 \mathrm{~m}$ (Fig. 4) have zero palynomorph marine index values which suggest a fresh water environment. 


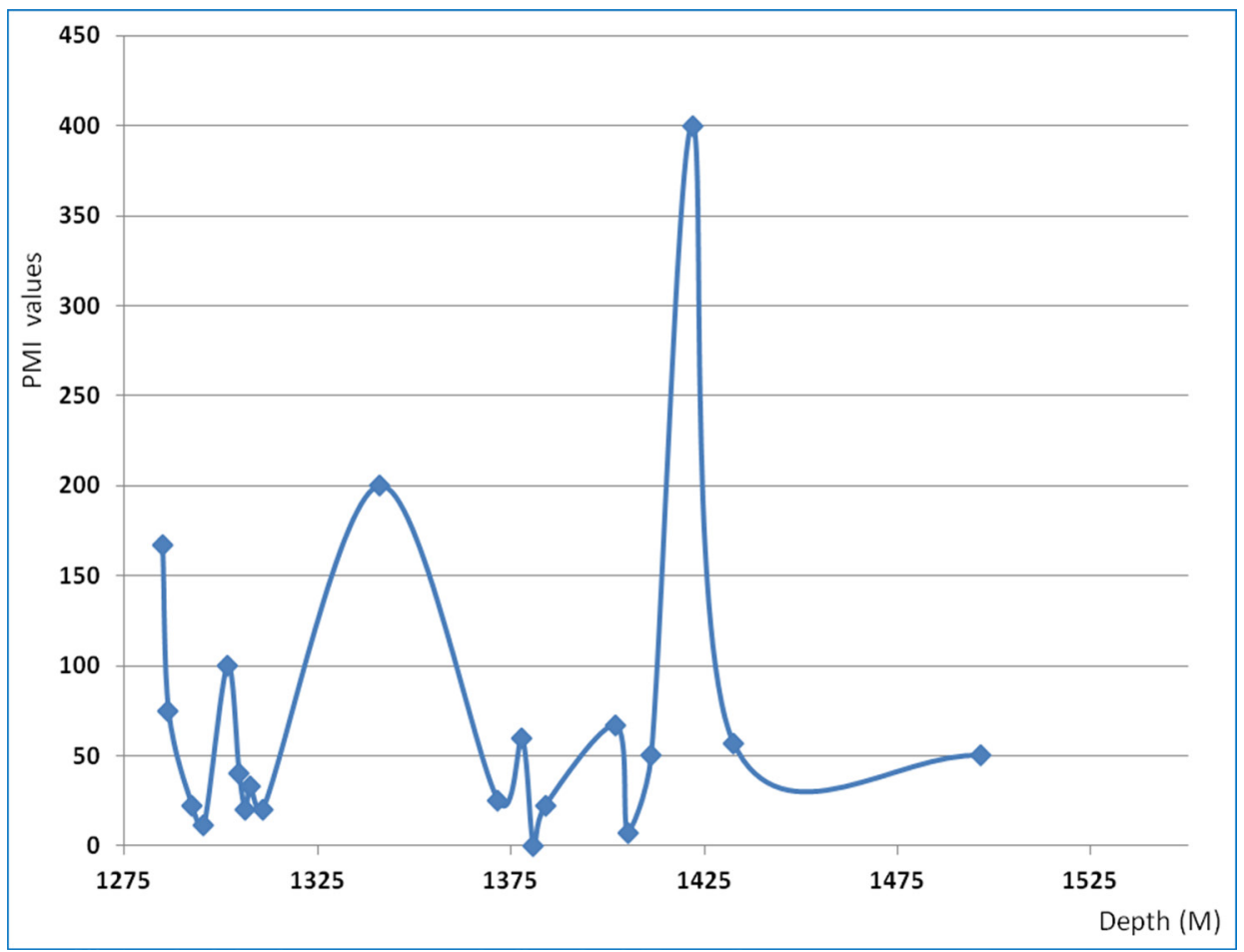

Fig. 4. Palynomorphs Marine Index Chart (PMI) for the Amansiodo-1 well

These intervals consist of moderate records of pollen and spores with diagnostic marker species such as: Monocolpites marginatus, Longapertites marginatus, Echitriporites trianguliformis, Retidiporites magdalenensis, and Cyathidites minor, also suggest a brackish to fresh water environment (Okeke \& Umeji 2016).

\section{CONCLUSIONS}

The lithology of the studied ditch cutting samples of a section of the Amansiodo-1 well (1284.73$1496.57 \mathrm{~m}$ ) is composed of black, hard and fissile shale. These samples were subjected to palynostratigraphic analysis to determine their age and depositional environment. The palynomorph assemblages recorded in the samples include spores, pollens and dinoflagellate cysts. An assemblage zone of Echitriporites trianguliformis Zone was established. The studied section is dated to the upper Maastrichtian based on the stratigraphical ranges of marker species. The PMI plot and the environmentally diagnostic marker species suggest that the sediments of the studied interval were deposited within marine to brackish water (coastal) environments with minor fresh water incursions. Coastal environments are suitable environments for hydrocarbon accumulation and exploration. The palynological analysis has contributed to the biostratigraphic zonation, age dating and paleoenvironmental studies of the Anambra Basin where the studied well is located.

The authors are grateful to the Geological Survey Agency of Nigeria, Kaduna for the provision of the ditch cuttings samples used for this work. We are also grateful to Crystal Age Limited, Lagos for providing the facilities necessary for the analysis.

\section{REFERENCES}

Benkhelil J. \& Guiraud R., 1980. La Benoue. Une chaine intracontinentale de style atlasique. Compte Rendu Academics du Sciences (Paris), 290, 1517-1520.

Chiaghanam O.I., Nwozor K.K., Chiadikobi K.C., Omoboriowo A.O., Soronnadi-Ononiwu C.G., Onuba L.N. \& Ofoma A.E., 2013. Lithofacies, palynology and paleoenvironmental study of Early Campanian to Mid-Maastrichtian deposits of Udi and Environs in the Anambra Basin, Southeastern Nigeria. International Journal of Science and Technology, 2, 453-470. 
Edet J.J., 1992. Palynostratigraphy of Late Cretaceous (late Campanian-early Maastrichtian) section in the Anambra Basin, Nigeria. Revista Española de Micropaleontología, 24, 3-18.

Eisawi A.A.M., 2015. Palynological Evidence of a Campanian-Maastrichtian Age of the Shendi Formation (Shendi Basin, Central Sudan). American Journal of Earth Sciences, 2, 206-210.

Evamy B.D., Haremboure J., Karmerling P., Knaap W.A., Molloy F.A. \& Rowlands P.H., 1978. Hydrocarbon habitat of Tertiary Niger Delta. American Association of Petroleum Geologists' Bulletin, 62, 1-39.

Hallsworth C.R. \& Knox R.W.O’B., 1999. British Geological Survey rock classification scheme. Volume 3: Classification of sediments and sedimentary rocks. British Geological Survey Research Report, 99-03.

Helenes J., De-Guerra C. \& Vásquez J., 1998. Palynology and Chronostratigraphy of the Upper Cretaceous in the subsurface of the Barinas area, western Venezuela. American Association of Petroleum Geologists' Bulletin, 82, 1308-1328.

Kogbe C.A., 1989. Paleogeographic history of Nigeria from Albian Times. [in:] Kogbe C.A. (ed.), Geology of Nigeria, $2^{\text {nd }}$ ed. Rock View Ltd., Jos, Nigeria, 257-275.

Lawal O. \& Moullade M., 1987. Palynological biostratigraphy of Cretaceous sediments in the upper Benue N.E. Nigeria (1). Review du Micropaléontologie, 29, 61-83.

Nwajide C.S., 1990. Cretaceous sedimentation and paleogeography of the central Benue Trough. [in:] Ofoegbu C.O. (ed.), The Benue Trough: structure and evolution, Friedr. Vieweg \& Sohn, Braunschweig and Wiesbaden, Germany, 19-38.

Nwajide C.S., 2005. Anambra Basin of Nigeria: Synoptic Basin Analysis as a Basis for Evaluation its Hydrocarbon Prospectivity. [in:] Okogbue C.O. (ed.), Hydrocarbon potentials of the Anambra Basin, PTDF Chair Nigeria, 2-46.

Ogala J.E., 2010. Palynology and biostratigraphic investigation of the Lower Coal Measure in Anambra basin, southeastern Nigeria. Global Journal Geological Science, $8,1596-6798$.

Ogala J.E., Ola-Buraimo A.O. \& Akaegbobi I.M., 2009. Palynological and palaeoenvironmental study of the Middle-Upper Maastrichtian Mamu Coal Facies in Anambra Basin, Nigeria. World Applied Sciences Journal, 7, 1566-1575.
Okeke K.K. \& Umeji O.P., 2016. Palynostratigraphy, palynofacies and palaeoenvironment of deposition of Selandian to Aquitanian sediments, southeastern Nigeria. Journal of African Earth Sciences, 120, 102-124.

Okoro A.U., 2012. Palynological Analysis of Late Cretaceous Sediments of the Nkporo Formation in the Afikpo Sub-basin, Southeastern Nigeria. Asian Transactions on Science and Technology, 2, 35-46.

Ola-Buraimo A.O. \& Akaegbobi I.M., 2013. Palynological and paleoenvironmental investigation of the Campanian-Lowermost Maastrichtian Asata/Nkporo Shale in Anambra Basin, Southeastern Nigeria. British Journal of Applied Science and Technology, 3, 898-915.

Onyekuru S.O., Okoro E.M., Opara K.D., Agumanu A.E. \& Ikoro D.O., 2017. Paleoenvironment and provenance studies of Ajali Sandstone in Igbere Area, Afikpo Basin, Nigeria. International Journal of Engineering and Science, 6, 19-30.

Reyment R.A., 1965. Aspects of the Geology of Nigeria. Ibadan University Press.

Salami M.B., 1990. Palynomoph taxa of the lower coal Measures deposits (Campanian- Maastrichian) of Anambra Basin southeastern Nigeria. Journal of African Earth Sciences, 11, 135-150.

Soronnadi-Ononiwu C.G., Omoboriowo A.O.J. \& Chukwujekwe N.V., 2012. Palynology and paleoenvironment studies of the Mamu Formation, Enugu area Anambra Basin. International Journal of Pure and Applied Sciences and Technology, 10, 1-6.

Stover L.E., Brinkhuis H., Damassa S.P., de Verteuil L., Helby R.J., Monteil E., Partridge A.D., Powell A.J., Riding J.B., Smelror M. \& Williams G.L., 1999. Mesozoic-Tertiary dinoflagellates, acritarchs and prasinophytes. [in:] Jansonius J. \& McGregor D.C. (eds.), Palynology: principles and applications, American Association of Stratigraphic Palynologists Foundation, 2, 641-750.

Umeji O.P. \& Edet J.J., 2008. Palynostratigraphy and paleoenvironments of the type area of Nsukka Formation of Anambra Basin, Southeastern Nigeria. Nigerian Association of Petroleum Explorationists' Bulletin, 20, 72-89.

Van Hoeken-Klinkenberg P.M.J., 1964. A palynological investigation of some Upper Cretaceous sediments in Nigeria. Pollen et Spores, 6, 209-231. 